\title{
1.9. Relacja mistrz-uczeń: próba interpretacji na podstawie refleksji nad autobiografią naukową Profesor Ireny Lepalczyk
}

\section{Wprowadzenie}

Udział w seminarium naukowym pt. Pedagogika społeczna: wstepy $i$ kontynuacje, które stało się przestrzenią do namysłu nad twórczością Profesor Ireny Lepalczyk w związku z dziesiątą rocznicą śmierci uczonej, okazało się dla mnie swego rodzaju wyzwaniem badawczym. Postanowiłam zagłębić się w lekturę autobiografii naukowej, traktując to dzieło jako zaproszenie do interpretacji, próby twórczego odczytania wydobywającego sens czy też sensy w niej tkwiące ${ }^{1}$. W rezultacie przemyśleń towarzyszących mi podczas analitycznej lektury ostatniej książki Ireny Lepalczyk pt. Wśród ludzi i ksiażek (2003), podjęłam decyzję, że pogłębioną analizę skoncentruję na relacji mistrz-uczeń.

Niniejszy tekst należy traktować jako zaproszenie do dyskusji, proponowanej przez pedagoga społecznego, który z racji metryki, nie miał osobistych styczności z Panią Profesor. Brak zetknięcia się z autorytetem osobowym Uczonej ułatwia krytyczne oraz analityczne myślenie, wolne od emocjonalnego zaangażowania (np. Granosik 2004), a z drugiej strony, stanowi istotną przeszkodę w obliczu podjęcia się zadania analizy biograficznej wypowiedzi autorki. Moją interpretację warto rozumieć jako zagajenie do dyskusji z Tymi, którzy współuczestniczyli w życiu naukowym Profesor Lepalczyk, to Oni najlepiej ocenią trafność zapre-

${ }^{*}$ Uniwersytet Łódzki, Wydział Nauk o Wychowaniu, Katedra Pedagogiki Społecznej.

${ }^{1}$ Moje obcowanie z autobiografią Ireny Lepalczyk zbliżone jest do jednego z wariantów statusu tekstu w trakcie lektury, który Lech Witkowski (2009a) określił jako „tekst jako pretekst” (ibidem, s. 135). W tym wypadku lektura oznacza m.in. poszukiwanie drugiego dna, uwypuklanie treści umiejscowionych między wierszami, wyczytywanie „ducha”, a nie litery (ibidem). 
zentowanej analitycznej recepcji fragmentu dzieła Wśród ludzi i ksiażek. Warto dodać, że niniejszym tekstem zapraszam do polemiki nie tylko nad trafnością dokonanej przeze mnie interpretacji wypowiedzi autobiograficznych autorki, ale również nad szerszym tematem, jakim jest relacja mistrz-uczeń we współczesnej rzeczywistości akademickiej.

Na początku chciałabym przedstawić założenia teoretyczne stanowiące punkt wyjścia podjętych rozważań, aby mój wywód zachował wymóg klarowności. Zacznę od tego, iż uznaję autobiografię naukową za formę autobiograficzną, która podobnie jak ,właściwa” autobiografia, czyli obejmująca przebieg całego życia człowieka, nie jest tylko napisanym tekstem, lecz wyraża coś więcej. Małgorzata Czermińska (2009, s. 9-13) to „,coś” określa jako „wzór życia” wydobyty ze zrekonstruowanych, minionych zdarzeń, połączonych z ich teraźniejszym oglądem. Przyjmuję zatem, że narracja pod postacią autobiografii naukowej jest pewną spójną całością, konstrukcja, w której odzwierciedlony jest subiektywny system relewancji narratora (por. Schütze 2012, s. 162-165). Z przyjętych przeze mnie założeń wynika, iż autor piszący swoją autobiografię naukową nie bez powodu pewne wątki rozbudowuje, inne ze sobą łączy, pozostałe marginalizuje, dalsze pomija. Nie bez powodu również relacjonuje je w określonej narracyjnej formie. Georges Gusdorf (2009, s. 37) uważa, że to właśnie posiadany „,postulat sensu” dyktuje wybór faktów i szczegółów, które należy opisać, a które pominąć. Oznacza to, iż lektura autobiografii umożliwia nie tylko poznanie życiorysu autora, ale również wgląd w określoną przez niego ,zrozumiałość” przeżyć, co genialnie określił Goethe w swoich wspomnieniach zatytułowanych Zmyślenie i prawda, mówiąc: ,pisze się takie rzeczy, aby przekazać innym teorię wszechświata, jaką nosi się w sobie (za: Gusdorf 2009, s. 38).

Moja uwaga - czytelnika studiującego dzieło Ireny Lepalczyk - była skupiona na próbie zrozumienia figury ,mistrza" w jej autobiografii, jako swoistego konstruktu, który naprowadza na tropy sensów, jakie można wydobyć poprzez sposób, w jaki ona sama postanowiła o tym napisać. Niniejszy tekst należy traktować jako interpretację autobiografii naukowej, napisaną z intencją poszukiwania tego, co „ukryte” lub zamieszczone ,między wierszami”, czego można poszukiwać w konstrukcji treści i w formie narracyjnej, a co charakteryzuje i przybliża relację Ireny Lepalczyk z jej mistrzynią - Heleną Radlińską.

\section{Narracja o mistrzu w przestrzeni całości autobiografii}

Irena Lepalczyk spośród wielu możliwości wyrazu, jakimi można się posłużyć, pisząc autobiografię naukową, wybrała styl kronikarski. Sama autorka explicite twierdzi, że właśnie w taki sposób opowiada o swojej drodze do nauki (Lepalczyk 2003, s. 154). Dzieło Wśród ludzi i ksiażek niewątpliwie można potraktować 
jako kronikę zawierającą znaczące osoby, wydarzenia, instytucje dla budowania zrębów pedagogiki społecznej i jej rozwoju. Kronikarski styl wypowiedzi I. Lepalczyk charakteryzuje się sprawozdawczą retoryką, rzeczowością przekazu oraz wręcz niebywałą dbałością o szczegół. W autobiografii autorki można znaleźć wiele fragmentów ukazujących precyzję protokołu, jak np.: wykaz wykładowców i nazwy przedmiotów, na jakie uczęszczała będąc studentką Działu Pracy Kulturalnej Uniwersytetu Łódzkiego - Wolnej Wszechnicy Polskiej (ibidem, s. 153-154), opis przebiegu egzaminu doktorskiego z wyszczególnieniem zagadnień, o które została spytana (ibidem, s. 169), listę recenzentów powołanych w trakcie procedury na tytuł profesora zwyczajnego (ibidem, s. 182), przebieg głosowania w sprawie nadania tytułu profesora zwyczajnego $(\text { ibidem })^{2}$. Równie szczegółowo i rzeczowo I. Lepalczyk nakreśla portrety osób znaczących „na jej drodze do nauki” oraz ich losy. Takich portretów w całej autobiografii jest bardzo wiele, ale dla zobrazowania, w czym rzecz, można przytoczyć fragment opowieści o Natalii Majewskiej-Nekraszowej, która posiadała bogatą biografię harcerską i od 1940 r. wydawała konspiracyjne pismo „Młodzież”. Autorka pisze o niej w następujący sposób:

Nieprzerwanie od 1937 do 1942 r. Nata była drużynową 13 WŻDH im. Marii Skłodowskiej-Curie. Na początku działań wojennych na wniosek komisarycznej komendantki Choragwi Stanisławy Laski Nata Nekraszowa objęła kierownictwo Pogotowia Harcerek Choragwi Warszawskiej. We wrześniu była komendantką Pomocniczego Szpitala Wojskowego nr 2 przy ul. Kopernika 13/15. W 1940 r. na parę miesięcy skierowana została do Terespola nad Bugiem na placówkę pograniczną PCK [...]. Po wojnie miałam z nią kontakt pośredni. W 1957 r. na zjeździe Związku Nauczycielstwa Polskiego została powołana Komisja Zagadnień Wychowawczych i Młodzieżowych. W jej ramach powstała Podkomisja do Spraw Samorządu Uczniowskiego. Przewodniczącym został A. Kamiński. Nekraszowa znalazła się wśród jej najbardziej aktywnych członków. Uczestniczyła w konferencjach. Prowadziła badania wśród uczniów szkół średnich. Na podstawie doświadczeń opiekunki samorządu gimnazjum w Łucku napisała artykuł „Bratnia pomoc - samorząd uczniowski w Gimnazjum Koedukacyjnym im. Tadeusza Kościuszki w Łucku”. Charakteryzuje w nim nie tylko dzieje i pracę samorządu, lecz także swoją w nim rolę. Przethumaczyła również pracę A. Ferriére’a pt. „Samorząd uczniowski we wspólnotach młodzieżowych” (ibidem, s. 99-100).

Kronikarski styl opowieści I. Lepalczyk o ludziach, instytucjach i ich losach, które przeplatały się z biografią samej narratorki ${ }^{3}$, sprawia, że Wśród ludzi i ksiqżek można potraktować jako dokument historyczny.

Narracja autorki nie zawiera tak wyraźnego połączenia życia zawodowego z prywatnym, jakie jest obecne np. w autobiografii Wincentego Okonia, peda-

${ }^{2}$ Ostatecznie Irena Lepalczyk nie otrzymała tytułu naukowego profesora zwyczajnego, co związane było z polityką kadrową, w której nie przewidywano nadania tytułu profesora zwyczajnego pracownikowi przygotowującemu się do emerytury (Lepalczyk 2003, s. 182).

${ }^{3} \mathrm{~W}$ dalszej części tekstu będę posługiwała się również pojęciem „,narratorka” jako synonimem określającym osobę Ireny Lepalczyk. Ma to również swoje uzasadnienie w przyjętym przeze mnie sposobie odczytywania autobiografii autorki, jako narracji autobiograficznej, która, w pewnym zakresie, staram się analizować w niniejszym tekście. 
goga z tego samego ,pokolenia historycznego"4, co narratorka, który prezentuje dziennik z jednego roku swojego życia, do którego dołączona jest autobiografia naukowa (2005). Dzieło uczonej nie zawiera treści pozwalających odtworzyć, jak to określa Zbyszko Melosik, „trajektorię rozwoju myślenia naukowego” (2010, s. 506), w której można odnaleźć proces dojrzewania tożsamości naukowej czy też wyraz recepcji poglądów, które wyznacza uprawiana subdyscyplina lub konkretna teoria pełniąca funkcję ramy paradygmatycznej określającej sposób postrzegania rzeczywistości dookoła nas (ibidem). Nie można zatem powiedzieć, że autobiografia Lepalczyk nosi w sobie znamiona ,psycho(auto)biografii naukowej" 5 , która umożliwia analizę procesu twórczego w kontekście biegu życia twórcy (Całek 2013, s. 68).

Należy jednak zaznaczyć, że w analizowanym dziele obecny jest również emocjonalny nurt narracji, który ,czyni przekaz bardziej wiarygodnym i osobistym" (Marynowicz-Hetka 2003b, s. 6). Warto zwrócić uwagę na fragment autobiografii, w którym autorka relacjonuje trudny etap dotyczący bezrobocia w latach 1949-19616, wynikającego z przerwy w istnieniu Katedry Pedagogiki Społecznej Uniwersytetu Łódzkiego. Autorka rozpoczyna tę część narracji, z właściwą sobie skrupulatną dbałością o szczegóły relacjonowanych zdarzeń, charakteryzuje formalne okoliczności jej zwolnienia związane z treścią otrzymanych dokumentów, które dostała zarówno ona, jak i Aleksander Kamiński. I. Lepalczyk przytacza treść listu, jaki A. Kamiński sformułował do Działu Personalnego UŁ w związku z otrzymanym wymówieniem, a także przedstawia zawartość dokumentacji Rady Wydziału Humanistycznego UŁ zawierającej przebieg rad, na których ważyły się losy jej dalszego zatrudnienia oraz zatrudnienia Kamińskiego. Początek tej części narracji nie odbiega od przyjętej konwencji wypowiedzi, która zbudowana jest na zasadzie kroniki z życia zawodowego, charakteryzowanej poprzez oficjalne wydarzenia z życia instytucji, w których uczestniczyła autorka. Zmiana sposobu narracji ujawnia się w dalszym fragmencie, który w całości cytuję poniżej, pogrubiwszy sformułowania szczególnie istotne dla prowadzonej analizy.

To była „droga przez mękę”. Znajdują się na niej podejmowane przez prof. H. Radlińską próby przeciwdziałania decyzjom Ministerstwa, m.in. interwencja u ministra oświaty S. Trojanowskiego,

${ }^{4}$ „Pokolenie historyczne” obejmuje wszystkie osoby, niezależnie od wieku, żyjące w danym czasie historycznym" (Marynowicz-Hetka 2006a, s. 510).

${ }^{5}$ Określenie w oryginalnej wersji dotyczy biografii, a nie autobiografii naukowej (Całek 2013, s. 68).

${ }^{6} 15$. grudnia 1949 r. Irena Lepalczyk otrzymała wymówienie z pracy na Uniwersytecie Łódzkim, zwolniona została zgodnie z treścią tego wymówienia ,z dniem 31 grudnia 1949 roku” (Lepalczyk 2003, s. 166). W 1961 r. reaktywowano Katedrę Pedagogiki Społecznej Uniwersytetu Łódzkiego. 1. października 1962 r. Lepalczyk została adiunktem w Katedrze Pedagogiki Społecznej” UŁ (Profesor Irena Lepalczyk 1966, s. 8). 
asystenta A. B. Dobrowolskiego na WWP. Idzie choćby o nominację roczną lub półroczną - pisze w liście do Wandy Wyrobkowej z dnia 24 września i dodaje: Kamykowi pomaga wiele osób. Można by wprowadzić w grę Obrączkową i jej przyjaciół - pisze w innym liście. Zawiadamia, że prof. B. Suchodolski rozmawiał ze S. Skrzeszewskim. Kiedy czytalam te listy, moje wzruszenie i równocześnie zażenowanie były ogromne. Wdzięczność dla prof. Heleny Radlińskiej, podejmującej $\mathrm{z}$ uporem przegraną sprawę, połączyla się z refleksją nad granicami ludzkiej dobroci i przyjaźni (Lepalczyk 2003, s. 167).

Powyższy ustęp ma charakter bardziej osobisty niż główny, sprawozdawczy, nurt narracji. Kiedy, podczas lektury, natknęłam się na ten fragment, stało się dla mnie jasne, że autobiografia Lepalczyk zawiera, poza sprawozdawczym nurtem narracji, jeszcze jeden, ten emocjonalny, osobisty. Rozpoczęłam odnajdywanie wypowiedzi zabarwionych sentymentalnie, odkrywających przeżycia wewnętrzne autorki. Tym sposobem podjęłam się analizy jednego z wątków, jaki silnie zaznacza się w przytaczanej autobiografii naukowej, a mianowicie ,relacja mistrz -uczeń", której poświęcę resztę tekstu.

\section{„Mistrz w obszarze myśli” - iluminacja}

Jednym ze znaczących wątków, które stanowią część osobistego nurtu narracji w autobiografii I. Lepalczyk, jest relacja, jaka rozwijała się pomiędzy nią a Heleną Radlińską. Można tę relację opisać przez pryzmat związku, jaki zachodzi pomiędzy uczniem, a mistrzem. Przy czym należy wyjaśnić sposób, w jaki rozumie się pojęcie „mistrzostwa”.

Otóż, mistrzostwo można rozumieć nie tylko jako cechę osoby, ale również jako specyfikę relacji, w której możliwe jest zidentyfikowanie mistrza i ucznia (Piekarski 1997, s. 18). Jacek Piekarski zaznacza, że mistrzostwo w ujęciu relacyjnym stanowi atrybut, który nadają nam inni, kiedy uznają się za naszych uczniów (ibidem). Relacyjny wymiar mistrzostwa również wiąże się z działaniem względem ucznia, w którym potwierdza się ów atrybut. W tym sensie należy mówić nie tyle o posiadaniu, ile o potwierdzaniu mistrzostwa (ibidem).

Teresa Bauman (2004, s. 73) również zwraca uwagę na kategorię mistrzostwa z perspektywy relacji mistrz-uczeń. Wymienia charakterystyczne fazy dla takiej relacji, które składają się na: „naśladowanie mistrza”, kiedy dominuje chęć upodobnienia się do niego; ,partnerstwo”, gdy uczeń zaczyna kształtować własną tożsamość naukową i wyrażać dojrzała, samodzielną refleksję; , przekraczanie", pozwalające uczniowi odejść od swojego mistrza i odkryć własną drogę.

Co można powiedzieć, na podstawie wnikliwej lektury Wśród ludzi i ksiażek, o charakterze tej relacji, jaka łączyła Irenę Lepalczyk z Heleną Radlińską? Na to pytanie będę starała się odpowiedzieć w niniejszym tekście. 
I. Lepalczyk niejako „otwiera” wątek dotyczący swojej Mistrzyni słowami:

Zaczęło się od iluminacji, od pierwszego kontaktu z tekstem prof. Heleny Radlińskiej z jej książki „Stosunek wychowawcy do środowiska społecznego [podkr. I.K.]. Szkice z pedagogiki społecznej" [...] Nie mam wątpliwości, że recepcja myśli Radlińskiej miała charakter emocjonalny i selektywny. Pewnego rodzaju rewelacją była idea, że zamierzenia mogą stać się rzeczywistością, a rzeczywistość wyrasta z marzeń. Przecież wiele prac podjętych przez młodzież harcerską zamieniało marzenia w rzeczywistość, a rzeczywistość- wbrew tragicznym realiom życia- była opromieniona marzeniami (2003, s. 149-150).

Autorka autobiografii opisuje w tym fragmencie symboliczny poczatek jej relacji z H. Radlińska, która przemawia do niej poprzez tekst i zostaje usłyszana w sensie „realnym”. Spróbuję wyjaśnić tak sformułowany wniosek, odnosząc się do stanowiska Lecha Witkowskiego, który, analizując twórczość Zygmunta Mysłakowskiego (2009b), wyodrębnia „dydaktykę przeżycia” (ibidem, s. 406-410). L. Witkowski zwraca uwagę, że realność kontaktu z tekstem polega na zrozumieniu go poprzez związek z własnymi przeżyciami, odczytanie ukrytych w nim znaczeń w połączeniu z ,potrzebami, pragnieniami, uczuciami, wzruszeniami, oczekiwaniami" czytającego (ibidem, s. 407). Takie obcowanie z tekstem sprawia, że przestaje on być dla nas „niemym” obiektem kultury (ibidem, s. 406), co pozwala na kontakt z mistrzem w „obszarze myśli’” (Bauman 2004, s. 75). W przytoczonym fragmencie I. Lepalczyk daje wyraz olśnieniu, jakiego doznała pod wpływem lektury H. Radlińskiej. Jest to „spotkanie" z tekstem, nabierające rangi wydarzenia ${ }^{8} \mathrm{w}$ życiu autorki, które można określić jako „biograficzną epifanię" ze względu na iluminację, czyli odkrycie tego, co wcześniej pozostawało ukryte (Kafar 2011). Myślę, że pierwszy kontakt I. Lepalczyk z dziełem H. Radlińskiej można uznać za wydarzenie epifaniczne również dlatego, iż symbolicznie otwiera ono rozdział w jej życiu związany z zainteresowaniem pedagogiką społeczną (Lepalczyk 2003, s. 149). Poprzez realny kontakt z tekstem Radlińskiej, Lepalczyk przeżywa epifanię, która

działa niczym niezmywalny marker; wyznacza cezurę dzielącą życie na „przed" i ,po”, na „wtedy” i „teraz” (Kafar 2011, s. 51).

${ }^{7}$ Teresa Bauman wyróżnia dwa sposoby kontaktu z mistrzem. Pisze o „mistrzach w obszarze myśli”, którzy przemawiają poprzez swoje dzieła zawierające „nadwyżkę sensu”, co sprawia, że czytelnicy odnajdują w nich własne inspiracje pozwalające tworzyć nowe koncepcje. Zdaniem autorki, można mówić również o „mistrzach w obszarze działania”, tych, z którymi kontaktujemy się bezpośrednio, których słuchamy i obserwujemy (2004, s. 73-75).

${ }^{8}$ Używam pojęcia ,spotkanie”, mając na myśli sposób, w jaki rozumie je Józef Tischner, który pisze: „Spotkać to coś więcej niż mieć świadomość, że inny jest obecny obok mnie lub przy mnie. Wmieszany w uliczny tłum mam świadomość, że obok mnie są inni ludzie, co jednak nie znaczy, że ich spotykam. Spotkanie jest wydarzeniem" (Tischner 2006b, s. 19).

${ }^{9}$ Pojęcie to można rozumieć jako świecką epifanię, czyli ,iluminację wyposażającą w całkiem nowe <widzenie> spraw, rozbłyskujących w nieznanej przedtem tonacji światła" (Gornat 2006, s. 23-24, za: Kafar 2011, s. 46). 
Można przypuszczać, że zetknięcie z dziełem H. Radlińskiej dotknęło ją do żywego, wywołało iluminację ze względu na to, że odnalazła w nim nadrzędną ideę, jaką kierowała się w swoim życiu i pracy harcerskiej, która mówiła o tym, iż „zamierzenia mogą stać się rzeczywistością, rzeczywistość wyrasta z marzeń” (Lepalczyk 2003, s. 150). Być może Lepalczyk zafascynowała się prospektywizmem, silnie zaznaczającym się w twórczości H. Radlińskiej, inspirującym do postawy czynnej wobec środowiska, którą wyraża myśl, że w każdych warunkach można przeciwstawiać się temu, co ogranicza działanie oraz realizować cele ukierunkowane na lepszą przyszłość (Radlińska 1964a, s. 474).

Należy również podkreślić znaczenie kontekstu historycznego, w jakim narratorka po raz pierwszy styka się z dziełem Stosunek wychowawcy do środowiska społecznego. Był to bowiem czas II wojny światowej, zbiorowej trajektorii, jaką przeżywało wielu Polaków. Teksty H. Radlińskiej nasycone „,kodeksem etycznym niepokornych" wyrażającym się w nonkonformizmie, odwadze cywilnej, poszanowaniu godności każdego człowieka, wspólnej pracy dla dobra ogółu (Theiss 1984, s. 17), dla wielu czytelników mogły stanowić źródło siły do zachowania postawy czynnej, nawet w tak trudnych czasach. Świadczą o tym słowa Ireny Jurgielewiczowej ${ }^{10}$ :

Tak więc to, co było głoszone za dni, kiedy spokojnie toczył się nurt życia i co wówczas nie dawało kierunku naszym dążeniom, okazało swą wartość w dniach klęski, które mamy za sobą. Idee Heleny Radlińskiej wytrzymały najwyższe kryterium i co równie chyba ważne - umiało im też sprostać jej życie. [...] Czerpaliśmy z nich siły w dniach klęski, które minęły - czerpiemy je nadal w pracy i odbudowie (Przemówienia i referaty 1994/1995, s. 175).

Idee głoszone przez H. Radlińską znalazły podatny grunt w osobie I. Lepalczyk, która łączyła je z własnymi doświadczeniami wyniesionymi ze stylu życia harcerki oraz ideologii harcerskiej ${ }^{11}$. I. Lepalczyk napisała, że:

Osobiście w „moim harcerstwie” [...] znajdowalam „moją pedagogikę społeczną” i jej Twórcę [podkr. J.K.] (Lepalczyk 2003, s. 112).

Autorka najwyraźniej zintegrowała własne przeżycia związane z działalnością harcerską z ideami H. Radlińskiej, być może właśnie taki „moment” stał się iluminacja, o której mowa we wcześniej przytoczonym fragmencie.

${ }^{10}$ Fragment Przemówienia Ireny Jurgielewiczowej wygłoszonego podczas zjazdu słuchaczy Studium Pracy Społeczno-Oświatowej WWP z okazji 50-lecia pracy naukowej Heleny Radlińskiej 25 maja $1947 \mathrm{r}$.

${ }^{11}$ Ideologia harcerska była przesycona wartościami kształtującymi etos człowieka Ireny Lepalczyk, które można sprowadzić do trzech nadrzędnych: optymizm, dzielność i perfekcjonizm rozumiany jako „trwałe dążenie do doskonalenia własnej osobowości” (Lepalczyk 2003, s. 136). 


\section{Relacja $\mathrm{z}$,mistrzem w obszarze dzialania" 12}

Znaczącym okresem biograficznym dla Ireny Lepalczyk było podjęcie studiów na Państwowym Kursie Pedagogicznym, którego opiekunem, była Helena Radlińska. Od tego momentu rozpoczyna się opowieść autorki o mistrzu w obszarze działania ${ }^{13}$, z którym ma się bezpośredni kontakt, którego się obserwuje i słucha (Bauman 2004, s. 75). Interesujący wydaje się sposób, w jaki narratorka opisuje relację z Heleną Radlińską od czasów kursu, po studia na tajnej Sekcji Społeczno-Oświatowej Wydziału Pedagogicznego Wolnej Wszechnicy Polskiej. Nawiązuje ona do zdarzeń, w których mistrzyni wyraziła wobec niej słowa krytyki:

[W czasie studiów w ramach Państwowego Kursu Pedagogicznego] Na zakończenie kursu nauczycielskiego pod opieką prof. Radlińskiej przygotowałam pracę dyplomową na temat Uniwersytetów Ludowych. Radlińska skrytykowała ją słowami, które dobrze zapamiętałam: „Najgorzej jest pracować ze studentkami, które zajmują się publicystyką" (byłam wówczas członkiem redakcji czasopisma „Młodzież”) (Lepalczyk 2003, s. 151).

[W czasie studiów na tajnej Sekcji Społeczno-Oświatowej WWP] Na seminarium z pedagogiki społecznej ponownie zostalam skrytykowana przez prof. Radlińską. Odbyło się to w ten sposób, iż mój referat, którego podstawą był artykuł Zofii Gulińskiej na temat Uniwersytetów Ludowych w Danii, a dokładnie na temat Mikołaja Gruntviga, przedstawiałam aż przez dwa kolejne seminaria. W istocie były one wypełnione wspaniałymi uzupełnieniami pani profesor (ibidem, s. 152).

Powyższe fragmenty, wyodrębnione z całości narracji, można potraktować jako przemawiające o jakości relacji, w której słowa nauczyciela-mistrza są słowami autorytetu, którego uważniej się słucha (Marynowicz-Hetka 2013, s. 38) i głębiej zapadają w pamięć, poruszają. Lepalczyk pisała przecież swoją autobiografię, będąc na emeryturze (Marynowicz-Hetka 2003b, s. 6), w czasie swojego życia, kiedy wiele opisywanych osób, zdarzeń, miejsc, było dla niej dawnym wspomnieniem. Mimo to narratorka wydobywa z pamięci konkretne sytuacje, słowa związane z osobą Radlińskiej, co świadczy o tym, że miały dla niej szczególne znaczenie. Za takim wnioskiem przemawia to, iż zaprezentowane fragmenty tekstu wyróżniają się na tle nurtu narracji na temat okresu studiów tym, że jako jedyne opisują konkretne, pojedyncze wydarzenia. Autorka uruchamiając własny system relewancji, który odzwierciedla się w unikatowej strukturze narracyjnej, skondensowała własną autobiografię naukową do zdarzeń istotnych, tworzących całość konstrukcji, w której zazwyczaj nie pojawiają się tak detaliczne nawiązania do poszczególnych zdarzeń ${ }^{14}$. Słowa krytyki tak silnie zapadły narratorce w pamięci, być może dlatego,

${ }^{12}$ Patrz przyp. 7.

${ }^{13}$ Można powiedzieć, że I. Lepalczyk miała to szczęście, że jej mistrzynią stał się „wielki człowiek tworzący wielkie dzieła" (Bauman 2004, s. 75).

${ }^{14} \mathrm{~W}$ literaturze dotyczącej metody wywiadu narracyjnego opracowanej przez Fritza Schütze tego rodzaju fragmenty są określane jako „sceny”, które poprzez swą narracyjną formę wskazują na znaczące miejsce w doświadczeniach narratora (por. Czyżewski, Rokuszewska-Pawełek 1989, s. 35). 
że był to początkowy etap w rozwijającej się relacji mistrza z uczniem, charakteryzujący się ,uwielbieniem, zachwytem nad wielkością mistrza, emocjonalnym poddaniem się jego urokowi" (Bauman 2004, s. 73). I. Lepalczyk pisze o swoim „zauroczeniu” zajęciami z Profesor Radlińską (Lepalczyk 2003, s. 153), o „niezapomnianych” spotkaniach w ,pokoiku” mistrzyni (ibidem, s. 152).

Relacja, jaką nawiązuje uczennica ze swoją mistrzynią, wkracza na inny poziom, kiedy po oswobodzeniu Warszawy ${ }^{15}$ I. Lepalczyk odszukuje H. Radlińską w Milanówku. Zapada wtedy decyzja o wspólnym wyjeździe do Łodzi. Postanowienie o pójściu za swoim mistrzem ${ }^{16}$ owocuje wprowadzeniem w środowisko skupione wokół osoby H. Radlińskiej oraz Wolnej Wszechnicy Polskiej. Tak oto pisze o tym sama autorka:

Babcia wprowadziła mnie w swoje środowisko. Dobrze czułam się w tym gronie, mimo różnicy wieku i, co ważniejsze, statusu społecznego i miejsca w hierarchii uczelnianej. [...] Dzięki nim znalazłam się w kręgu osób, które darzyły mnie życzliwością. Podobnie jak więzi harcerskie, związki z nimi okazały się trwałe i wywołują nieprzerwanie uczucia wdzięczności. Radlińska oraz jej bliscy znajomi i przyjaciele sprawiali, że wewnętrznie rosłam i dojrzewalam (ibidem, s. 258).

I. Lepalczyk, dzięki H. Radlińskiej, staje się częścią środowiska składającego się z byłych wykładowców Wolnej Wszechnicy Polskiej, jak: profesorowie Maria Librachowa, Natalia Gąsiorowska-Grabowska, Jan Muszkowski czy Sergiusz Hessen oraz oddanych uczniów „Babci”: Anna Bogusławska, Staszka Oprawska, Wanda Wyrobkowa-Pawłowska, Irena Kryczyńska. Środowisko skoncentrowane wokół mistrzyni charakteryzuje, poza wspólnotą zainteresowań, również specyficzny klimat emocjonalny, który uwidacznia się we wręcz „familijnych” stosunkach wzajemnych. Jak zauważa Jerzy Grobis, tego rodzaju relacje dziś moga jawić się jako społeczny anachronizm w czasach, gdy

jesteśmy [...] świadkami nowego zjawiska, występującego w masowej skali, a mianowicie, rozpadu bezpośredniej emocjonalnej więzi między mistrzem a uczniem (1997, s. 76).

W każdym razie nie sposób nie zgodzić się z Ewą Marynowicz-Hetką (2013, s. 37-38), która zauważa, iż niezwykły potencjał intelektualny, emocjonalny i działaniowy H. Radlińskiej ${ }^{17}$ sprawił, że okres, w którym rodziła się pedagogika

${ }^{15}$ Po upadku Powstania Warszawskiego H. Radlińska przechodzi obóz w Pruszkowie. Następnie mieszka w Milanówku, gdzie odwiedza ją I. Lepalczyk (Theiss 1984, s. 33).

${ }^{16}$ Nie są znane motywy decyzji I. Lepalczyk. Czy postanowiła wyjechać z Radlińską do Łodzi ze względu na swoją fascynację jej osobą i pedagogiką społeczną? Czy po prostu zamierzała dokończyć studia i uzyskać tytuł magistra? A może taka decyzja, ze względu na losy wojenne jej rodziny, była najrozsądniejsza w tamtym czasie? Autorka nie udziela odpowiedzi na te pytania, ale ich wyartykułowanie wydało mi się ważne ze względu na pułapkę opowiadania mitu o mistrzu i uczniu.

${ }^{17}$ Sergiusz Hessen tak oto pisze w liście do Heleny Radlińskiej z 22.05.1947 r. o aurze, jaką ona roztaczała wokół siebie: „Zwłaszcza podczas wojny podziwiałem hart ducha Pani należąc do 
społeczna, można określić jako czas, w którym była ona żywa, jako ,instytucja symboliczna"18. W tym sensie, jeśli mówimy o szkole myślenia, jaką była w tamtych czasach pedagogika społeczna, to należy uwzględnić nie tylko ,swoisty typ dyskursu wyodrębniony na podstawie instytucjonalnej identyfikacji uczestników" (Piekarski 1997, s. 19), ale również aspekt aksjologiczny, jaki ją spajał. Grono skupione wokół H. Radlińskiej stanowili bowiem ludzie o ,wysokim poziomie duchowym" (Depesze i korespondencja 1994/1995, s. 188) ${ }^{19}$.

Związek I. Lepalczyk z H. Radlińską przeradza się w relację przyjaźni, jaka łączyła „Babcię” z jej ,wnukami” - oddanymi uczniami, którzy przychodzili po poradę, nie tylko w sprawach naukowych, ale również życiowych (Lepalczyk 2003, s. 255). Dla których była ona mędrcem i przyjacielem, a nawet kimś więcej - przewodnikiem, guru (por. Bauman 2004, s. 71).

[Fragment wypowiedzi Hanny Bogusławskiej] ${ }^{20}$ Helena Radlińska wykreśliła linię - myśl zainteresowań umysłowych i dążeń, a przywiązanie do niej i milość córki nigdy mnie nie opuszczały (Lepalczyk 2003, s. 255).

Szczególna więź, jaka spajała H. Radlińską z jej uczniami, stała się udziałem również I. Lepalczyk, co wyraźnie widać w poniższym fragmencie narracji:

Warto tu dodać, że moja matka i siostra w czasie, gdy mieszkały w Gliwicach, należały do osób, które Babcia ogarniała swoją życzliwością, m.in. zapraszając na doroczne święta. Moja siostra podczas trudności z opałem spowodowała dostawę węgla prosto ze Śląska. Wełniana narzuta na tapczan oraz poszewka na poduszkę H. Radlińskiej to także wyraz jej troski, podobnie jak materiał na kostium. Moja rodzina otrzymała również wiele dowodów serdecznego myślenia. Wystarczy przeczytać niektóre listy Babci adresowane do mnie. Dlaczego piszę o tych pozornie drobnych sprawach? Po pierwsze - w latach powojennych nie byly drobne, po drugie - były przejawami i dowodami szeroko otwartych serc, charakterystycznych dla czlonków Rodziny Ludzkiej. Żałuję, że nie jestem poetką (ibidem, s. 258).

Związek narratorki z jej mistrzem nabiera charakteru prywatnego, wykraczającego poza sferę spraw nauki. Uczniowie H. Radlińskiej byli zachęcani do przejawiania otwartej postawy względem mistrzyni, która wykazywała wobec nich stosunek wychowawczy i opiekuńczy (por. Sala 1994/1995, s. 115). Z czasem,

tych, którzy byli w zasięgu ciągle szerzącego się promieniowania osobowości Pani. Było to promieniowanie wiedzy, radości, miłości, które podtrzymywało na duchu zmęczonych i dodawało sił walczącym" (Depesze i korespondencja 1994/1995, s. 190).

${ }^{18}$ Ewa Marynowicz-Hetka podaje, za Castoriadisem, iż instytucję symboliczną można rozumieć jako „sieć symboliczną, społecznie usankcjonowaną, w której krzyżują się, w zróżnicowanych relacjach i proporcjach, elementy realne i wyobrażalne" (Marynowicz-Hetka 2006a, s. 507).

${ }^{19} \mathrm{Z}$ listu Bronisławy Bobrowskiej z 22.05.1947 r.

${ }^{20}$ I. Lepalczyk podaje, że H. Bogusławska napisała te słowa w 90. roku życia (Lepalczyk 2003, s. 255). 
w przypadku niektórych relacje te przeradzały się w niezwykle silne, pełne oddania, przyjacielskie ${ }^{21}$.

Warto również zauważyć, że charakter więzi łączącej uczennicę z mistrzynią wpisuje się w pewien fenomen obecny w środowisku pedagogów społecznych w czasach powojennych, który można określić pojęciem la gratuité, oznaczającym nieodpłatne, dobrowolne dawanie (Caillé, Chamail 2010, za: Marynowicz-Hetka 2012, s. 167) 22. Taka atmosfera sprzyjała umacnianiu relacji mistrz-uczeń, które opierały się na „wzajemności przyjaznej” (reciprocité amitié/philia) (ibidem, s. 169), w której ,nikt nie czuje się wykorzystywany, ma poczucie równości i wolności, ale równocześnie odczuwa, że jest w jakimś sensie wybranym (jedynym)" (Bruni 2010, s. 229, za: Marynowicz-Hetka 2012, s. 169).

\section{Związek mistrza z uczniem jako relacja ,wymiany darów”}

Związek I. Lepalczyk z H. Radlińską przechodzi na kolejny etap w okresie przymusowego intermedium narratorki. Był to czas, w którym uczennica towarzyszy swojemu mistrzowi w pracy badawczej i zwyczajnej codzienności.

Poza pisaniem pod dyktando pomagałam w dostarczaniu materiałów do bibliotek, w robieniu przypisów, jak potrafiłam, starałam się pomóc w pracy redaktorskiej. Nie miałam wątpliwości, że aż do śmierci prof. Radlińskiej-starałam się pomagać, nie tylko w przygotowaniu prac naukowych, lecz także w organizacji życia, załatwianiu spraw codziennych, porozumiewaniu się z ludźmi i instytucjami (Lepalczyk 2003, s. 217-218).

I. Lepalczyk pomagała swojej mistrzyni w pracy nad książkami: Listy o nauczaniu i pracy badawczej (Radlińska 1964b) oraz Stanisława Michalskiego autobiografia i działalność oświatowa (1967). Narratorka przyznaje, że był to dla niej okres „trudny i piękny” zarazem (Lepalczyk 2003, s. 220), gdyż prace badawcze podejmowały - schorowana profesor na emeryturze i jej bezrobotna współpracownica.

Z analizy narracji wynika, iż był to etap biograficzny w życiu I. Lepalczyk, w którym w pełni urzeczywistnił się charakter relacji ucznia w stosunku do swojego mistrza. Uczennica, poprzez zaangażowanie w relację ze swoją mistrzynią ujawniła swoistą obecność autorytetu żywionego w stosunku do Niej23 (Witkow-

${ }^{21}$ Przykładem może być korespondencja pomiędzy Heleną Radlińską a Wandą Wyrobkową-Pawłowską (1945-1954) (Listy o pedagogice społecznej 1997, s. 34-149).

${ }^{22}$ Aby lepiej zrozumieć charakter relacji łączących pedagogów społecznych w czasach powojennych, należałoby dodatkowo przeanalizować kontekst historyczny, w jakim one zachodziły.

${ }^{23}$ Chodzi tutaj o zwrócenie uwagi na obecność autorytetu, który nie jest gołosłowną deklaracją, ale wyraża się w działaniu „traktowania autorytetu serio”, jako „długu za ważne impulsy pomagające zmienić swoje nastawienie do życia, siebie samego i świata dookoła” (Witkowski 2011, s. 733). 
ski 2011, s. 733). Był to czas, kiedy narratorka stała się pomoca, u boku mistrza, ale również mogła czerpać z niego, poszukiwać „bogactwa przeżyć intelektualnych” oraz odczuwać „szczęście kontaktu z wielką osobowością” (Lepalczyk 2003, s. 175). Tak oto sama autorka wypowiada się o tym ,trudnym i zarazem pięknym” etapie jej życia u boku mistrza:

Czasem myślę, że gdybym z zakresu pisarstwa naukowego nic więcej nie zrobiła - to i tak powinnam być wdzięczna losowi za ten dar, jaki otrzymałam od Radlińskiej (ibidem, s. 220).

Warto zauważyć, iż relacja Ireny Lepalczyk z Heleną Radlińską może być odczytana z perspektywy „koncepcji daru” (por. Fustier 1998b, Mauss 1973), która obrazuje dynamikę budowania relacji opartej na dawaniu ,czasu, emocji, swej prywatności, swej indywidualności, po prostu siebie" (Marynowicz-Hetka 2006a, s. 141), w której ,dług nigdy nie będzie wyrównany, wprost przeciwnie: nieustannie narasta" (Fustier 1998b, s. 197). Mając na uwadze tę perspektywę, warto zadać pytania: jaki dar otrzymany od H. Radlińskiej miała na myśli I. Lepalczyk? oraz: w jaki sposób próbowała nań odpowiedzieć?

Lepalczyk w zakończeniu swojej autobiografii napisała:

Przemyślenia towarzyszące tym dwóm wydawnictwom ${ }^{24}$ zachęciły mnie do ukazania spraw w całokształcie życia, a przede wszystkim do dania sobie odpowiedzi, czy wypelnilam te zadania, które podjęłam po śmierci Radlińskiej. Starałam się nie zgubić podstawowych idei dyscypliny, zaczynając od przedstawienia myśli w zaczętych przez nią, a kontynuowanych przeze mnie pracach (Lepalczyk 2003, s. 317).

Powyższy fragment można potraktować jako egzemplifikację dynamiki relacji mistrz-uczeń, która wyzwala potrzebę odpowiedzi na „dar”. Narratorka w kilku miejscach swojej autobiografii pisze o poczuciu wdzięczności, jakie odczuwała wobec I. Radlińskiej (ibidem, s. 220, 258), co można tłumaczyć w kategoriach wdzięczności za pomoc, jaką od niej otrzymała ${ }^{25}$ oraz „długu wdzięczności za konkretne zyski rozwojowe" (Witkowski 2011, s. 737), jakie się w niej dokonały dzięki relacji z mistrzynią. Uczeń różnie może spożytkować to, co dostaje od mistrza, oraz odpowiedzieć na to, co otrzymuje. Narratorka w odpowiedzi na „dar” za swoje zadanie życiowe uznaje

upowszechnianie dyscypliny $w$ innych uczelniach i rozwinięcie oraz umocnienie w uczelni macierzystej (Lepalczyk 2003, s. 317). (1997a).

${ }^{24}$ Chodzi o prace I. Lepalczyk: Radości na trudnych drogach (1997b); Moje harcerstwo

${ }^{25} \mathrm{~W}$ czasie, kiedy I. Lepalczyk pozostawała bezrobotna, H. Radlińska podejmowała próby pomocy w poszukiwaniu zajęcia swojej uczennicy, czego ślad pozostał w Listach o pedagogice społecznej (1997), które I. Lepalczyk poznała dopiero w chwili wydania, a ich lektura wywoływała w niej bardzo silne emocje, jeszcze w czasie pisania autobiografii (2003, s. 214). 
Jak twierdzi autorka, autobiografia, którą napisała, była z jej strony próbą własnego rozliczenia się z życiowych zadań, które podjęła po śmierci H. Radlińskiej (ibidem, s. 317), co można traktować jako symboliczną odpowiedź na „dar” otrzymany od mistrza.

Przyglądając się stosunkom łączącym obie uczone, należy zwrócić uwagę również na ryzyko ich nazbyt emocjonalnego wymiaru. Warto się zastanowić, czy relacja je łącząca była charakterystyczna raczej dla sfery prywatnej, zarezerwowanej dla więzi rodzinnych, przyjacielskich. W przypadku nawiązania relacji opartej li tylko na „wymianie darów”, istnieje ryzyko „uwikłania”, polegającego na współtworzeniu relacji, której logika sprowadza się do wzajemnego obdarowywania aż do momentu, gdy pojawia się dar, który nie sposób odwzajemnić, na który nie sposób odpowiedzieć kolejnym darem (Fustier 1998b, s. 198-202; Kamińska 2013, s. 305-307). W tego rodzaju więzi pojawia się zależność polegająca na odczuwanej powinności odwzajemnienia daru, czyli oddania czegoś z siebie, z własnej osoby, na co można nie mieć chęci i gotowości (Fustier 1998b, s. 202). W takiej relacji jedna ze stron może poczuć się oszukana, zdradzona, odrzucona ze względu na brak odwzajemnienia daru (ibidem, s. 200). Warto również się zastanowić, czy w przypadku relacji mistrz-uczeń nazbyt emocjonalna więź nie przeszkadza w analityczno-krytycznym stosunku do dzieł mistrza. W końcu, jak pisze przywoływana już Teresa Bauman, kwintesencją relacji mistrz-uczeń jest przekroczenie mistrza, a nie stanie się jego apologetą (2004, s. 73).

\section{Relacja mistrza z uczniem jako formuła procesu dziedzictwa kulturowego}

Irena Lepalczyk podkreśla, że jako pedagog społeczny czuła się częścią większej całości, którą nazywa „łańcuchem spraw i ludzi” (2003, s. 318). Ów łańcuch, jak tłumaczy narratorka, oznacza wspólnotę ludzi utożsamiających się z ideą mającą moc

przyczyniania się, mimo trudności i przeszkód, do coraz skuteczniejszego przekształcenia środowiska ludzkiego (ibidem, s. 318).

Autorka autobiografii wiele miejsca poświęca ludziom, z którymi zetknęła się na swojej drodze naukowej i ich losom, co można rozumieć jako chęć ukazania rozwoju pedagogiki społecznej jako instytucji symbolicznej, łączącej określone osoby i ich dzieje (ibidem, s. 177, 251). Taki sposób prowadzenia narracji znajduje swoje uzasadnienie w poczuciu przynależności do polskiej szkoły pedagogiki społecznej, której spiritus movens była H. Radlińska (por. ibidem, s. 235). Przy czym ,szkołę” należy tutaj rozumieć jako instytucję symboliczną, charakteryzującą się wspólnotą idei i wartości, zgodnie z zasadą „zgodności myśli i czynów” 
(Theiss 1984, s. 9). W tym sensie uzasadnione wydają się głosy, które określają „szkołę” stworzoną przez H. Radlińską nie tylko jako grupę wytwarzającą dyskurs naukowy, ale również ideowy ruch społeczny (Depesze i korespondencja 1994/1995, s. 189²6; Miasto Społeczne Warszawa).

Odczuwana przez I. Lepalczyk przynależność do wspólnoty pedagogów społecznych świadczy o tym, że jej potrzeba upowszechniania i rozwijania pedagogiki społecznej nie wynikała tylko z poczucia wdzięczności dla mistrza i chęci odwzajemnienia ,daru”. Być może chodziło również o krzewienie i propagowanie określonych przekonań konstytutywnych dla pedagogiki społecznej tamtych czasów, związanych z udziałem wychowania w przebudowie społeczeństwa, wiarą w prymarną wartość człowieka, któremu należy stworzyć jak najlepsze warunki do jego rozwoju, co wiązało się z umożliwieniem demokratycznego rozwoju instytucji państwowych i społecznych (Theiss 1984, s. 10). Słusznie zauważa E. Marynowicz-Hetka (2013, s. 45), że metaforę użytą przez I. Lepalczyk - „łańcuch spraw i ludzi" - można odczytać jako formułę procesu dziedzictwa kulturowego (la filiation), która nakierowuje na rozważania związane z tym, „co się dziedziczy, jak się dziedziczy i jakie są uwarunkowania tego procesu” (ibidem, s. 35). Z tej perspektywy można wysnuć wniosek warty przedyskutowania, że Irena Lepalczyk jako „ogniwo łańcucha” realizowała swoją misję popularyzowania pedagogiki społecznej, ze względu na chęć przekazania dziedzictwa myśli i idei w nią wpisanej. Oznaczałoby to, że tłumaczenie relacji mistrz-uczeń, obecnej w biografii narratorki, przez pryzmat koncepcji daru, wymagałoby uzupełnień i wpisania tej relacji w głębię dziedzictwa kulturowego, w której dynamice istotne miejsce zajmuje

poczucie bycia spadkobiercą zobowiązujące do samodzielnego rozwijania idei i podążania w przyjętym kierunku (Witkowski 2011, s. 737).

Wątek uprawiania nauki w poczuciu uczestniczenia w procesie dziedzictwa kulturowego, który jedynie zasygnalizowałam w refleksji nad autobiografią I. Lepalczyk, z pewnością wymaga szerszego omówienia i dalszych analiz. Inspirujące w tym względzie wydają się stanowiska Ewy Marynowicz-Hetki (2013) oraz Lecha Witkowskiego (2009b, 2011).

\section{Zakończenie}

W ostatniej części tekstu chciałabym przyjrzeć się obrazowi relacji mistrzuczeń, który wyłania się z autobiografii narratorki, pod kątem wniosków, jakie można nakreślić na podstawie takiej propozycji formuły udziału w rzeczywistości naukowej.

${ }^{26}$ List L. Chomińskiego do H. Radlińskiej z 24.05.1947 r. 
Przede wszystkim trzeba powiedzieć, że autorka autobiografii dojrzewała intelektualnie, rozwijała się naukowo w kontakcie z mistrzem, czyli tym, który „odkrył" nowy obszar wiedzy i posiadał moc gromadzenia wokół siebie innych, którzy podzielali fascynacje „odkrywaniem” pedagogiki społecznej (por. Bauman 2004, s. 79). Warto jednak podkreślić za Teresą Bauman, że „mistrz wyłania się w obszarze intelektualnego horyzontu ucznia" (ibidem, s. 72), a to oznacza pewne zagrożenia, jakie niesie ze sobą tego rodzaju relacja w sytuacji, gdy uczeń staje się naśladowca, apologetą albo jedynie kronikarzem własnego mistrza. W tym wypadku uczeń, niczym w hipnozie, podążając za swym mistrzem, jest niezdolny do twórczego, krytycznego, intelektualnego sporu, gdyż traktuje system naukowych poglądów mistrza jako dogmat, z którym się nie polemizuje (Witkowski 2009b, s. 94-98). W takiej sytuacji relacja mistrz-uczeń traci swój sens podstawowy, który sprowadza się do rozwoju wiedzy w danym obszarze. Dodatkowym aspektem, na jaki warto zwrócić uwagę, jest stworzenie pomiędzy uczniem a mistrzem relacji, która sprzyjałaby rozwojowi intelektualnemu, co, moim zdaniem, wymaga odpowiedniej równowagi, chroniącej przed „uwikłaniem się w spiralę darów” (por. Kamińska 2013, s. 305-307).

Warto zadać sobie pytanie, czy pedagogika społeczna stworzona przez Helenę Radlińską - mistrza, który posiadał wielu uczniów, była w czasach jej wczesnego rozwoju „szkołą myślenia”, charakteryzującą się wspólną płaszczyzną mentalną jej członków polegającą na zgodzie co do tego, ,jak się myśli”, a nie „co się myśli” (Bauman 2004, s. 78). Członkowie szkoły myślenia podzielają przekonania co do wagi zadawania określonych pytań i formułowania specyficznych twierdzeń, ale wyróżnia ich zarazem „nieposłuszeństwo w myśleniu”, które świadczy o umiejętności wyjścia „poza” horyzont mistrza i przekroczenia go w drodze rozwoju twórczego (por. ibidem, s. 78). Zbierając materiały do niniejszego tekstu, w pewnym momencie natrafiłam na wypowiedź Władysława Sali, jednego z pierwszych studentów Studium Pracy Społeczno-Oświatowej Wolnej Wszechnicy Polskiej, który tak oto wspomina intelektualną atmosferę z czasów studiów:

I tu właśnie ${ }^{27}$ omawiano na żywo każde wystapienie „Babci Radlińskiej”, spierano się o właściwe rozumienie jej pedagogiki społecznej (Sala, 1994/1995, s. 112).

Słowa te zainspirowały mnie do namysłu nad charakterem ówczesnej, rodzącej się szkoły pedagogiki społecznej. Czy była to szkoła naukowa, która jednocześnie posiadała walory szkoły myślenia? Czy intelektualne spory nad tym, jak należy „interpretować Radlińską” występujące wśród uczniów, a pewnie również wśród wykładowców, toczyły się wokół klucza „kto ma rację” w „odczytaniu Ra-

${ }^{27}$ Sala opowiada o spotkaniach mających miejsce w Ognisku Oświatowym przy ul. Wolskiej 44 w Warszawie, gdzie zamieszkiwali studenci Wolnej Wszechnicy Polskiej. 
dlińskiej”, a nie w czym warto się z nią zgodzić, co zmienić, co odrzucić, co dodać, co zbudować inaczej?

Tego rodzaju pytania uzmysłowiły mi, że podejmując namysł nad relacją mistrz-uczeń, należy pamiętać o jej istocie, która polega na ,przekroczeniu” mistrza, pójściu własną drogą twórczą, polegającą na rozwinięciu idei przez niego zapoczątkowanych, odkryciu czegoś nowego (Bauman 2004, s. 73). Formuła kontaktu mistrza z uczniem, jeśli wyzwala odkrywcze, intelektualne spory i nie prowadzi do dogmatyzmu myślenia, daje szansę na twórczy rozwój w kontakcie z charyzmatyczną osobowością. O tym należy pamiętać szczególnie wtedy, gdy z gruntu odrzuca się tego rodzaju formułę kontaktów w społeczności akademickiej, traktując ją jako zaśniedziała, archaiczną czy po prostu historyczną. 